\title{
INDONESIAN CULTURAL IDENTITY IN THE MESSAGE OF PUBLIC SERVICE ANNOUNCEMENTS FROM FILM SENSOR INSTITUTIONS 2014
}

\author{
Agus Hermanto \\ University of Muhammadiyah Jakarta, Indonesia \\ agushermanto2000@gmail.com \\ Sa'diyah El Adawiyah \\ University of Muhammadiyah Jakarta, Indonesia \\ ellaadawiyah25@gmail.com
}

\begin{abstract}
This study aims to determine the Indonesian cultural identity, visual forms of identity, and the visual meaning of Indonesian cultural identity in the message of Public service announcements at television from Film Sensor Institutions in 2014. This study is a qualitative research of constructivism paradigm with semiotics analysts. The findings of this study show the diversity of cultural identity has the potential that can be developed to have more value and added value, both from the economic side as well as from the social and cultural side. That traditional culture can be side by side and synergize with the advancement of time and the advancement of existing technology, can advance Indonesian traditional culture and Indonesian traditional culture can help technological advancement. It also shows that the diversity of Indonesian culture can be one of the drivers in the advancement of the film industry in Indonesia and film becomes a promotional tool for Indonesian cultural diversity.
\end{abstract}

Keywords: Indonesian Cultural Identity; Public Service Announcements

\begin{abstract}
Abstrak
Penelitian ini bertujuan untuk mengetahui identitas budaya Indonesia, bentuk visual identitas, dan makna visual identitas budaya Indonesia dalam pesan pengumuman layanan publik di televisi dari Lembaga Sensor Film pada tahun 2014. Penelitian ini adalah penelitian kualitatif paradigma konstruktivisme
\end{abstract}


dengan analisis semiotika. Temuan penelitian ini menunjukkan keanekaragaman identitas budaya memiliki potensi yang dapat dikembangkan untuk memiliki nilai lebih dan nilai tambah, baik dari sisi ekonomi maupun dari sisi sosial dan budaya. Bahwa budaya tradisional dapat berdampingan dan bersinergi dengan kemajuan waktu dan kemajuan teknologi yang ada, dapat memajukan budaya tradisional Indonesia dan budaya tradisional Indonesia dapat membantu kemajuan teknologi. Hal ini juga menunjukkan bahwa keanekaragaman budaya Indonesia dapat menjadi salah satu pendorong dalam kemajuan industri film di Indonesia dan film menjadi alat promosi untuk keanekaragaman budaya Indonesia.

Kata Kunci: Identitas Budaya Indonesia; Iklan Layanan Masyarakat

Accepted : April 21, 2020 Reviewed: May 6, 2020 Published: June 1, 2020

\section{Introduction}

Film Sensor Institutions fully understands that film as a work of cultural art has a strategic role in increasing the resilience of the nation's culture and the welfare of the people physically and spiritually to strengthen national resilience. Therefore, the state is responsible for advancing film that needs to be developed and protected by Indonesian films and films.

Film Sensor Institutions also looks at the diversity of cultures possessed by Indonesians from the many ethnic groups in Indonesia. As a socialization to the public, film and film advertisements can be made into a quality work of creation so that the Film Sensor Institutions tries to inform about new concepts in film censorship and education about how the diversity of Indonesian culture. Therefore, the work of creation can be an inspiration and theme in a film by making public service announcements.

Advertising is a reality of the portrait in society. Advertising is a portrait of reality that matches its character, which is found in society so that it can spread values related to social, cultural, political, etc. whereas Public Service Announcement (PSA) appear based on the condition of the country / community which is hit by a social problem so that the messages displayed are mostly social in nature (Vera, 2015). The main task of a PSA is to inform the social message to the community to be 
interested and follow it and then carry it out (Pujiyanto, 2014). The problem in this study is limited to the cultural identity of Indonesia in the message of public service announcements on TV from the Film Sensor Institutions in 2014.

The reseach question from the explanation is, "What is the meaning of the visual identity of Indonesian culture contained in the message of Public Service public service announcements on TV from Film Sensor Institutions in 2014?." The research objectives are to find out; (1) what is the identity, (2) design visual, dan (3) the visual meaning of the cultural identity of Indonesia in the message of public service announcements on TV from the Film Sensor Institutions in 2014.

This research is expected to be material for the development of cultural studies and Indonesian cultural identity; film studies and film censors; and communication studies, especially advertising, which focus on semiotic analysis. In addition, this research is expected to also be a reference or consideration by the Film Sensor Institutions, advertisers, further research, and parties interested in the world of advertising in conducting marketing communication programs (commercial marketing and social marketing) to be better.

\section{Research Method}

Qualitative constructivist paradigm research conducted in this study. Qualitative methods are often called constructive methods, because they function to construct findings into meaningful 'buildings' (Sugiyono, 2013).

The advertisement observed in this study is the 30 second duration version. This research focuses on Indonesian cultural identity in the message of public service announcements on TV from the Film Sensor Institutions in 2014 about what are the identities, visual forms, and what is the visual meaning. Research is done naturally, directly at the source under study, and more emphasis on meaning. This research is not merely seeking the truth, but rather on understanding the subject of the surrounding world. Data collection is carried out in a variety of settings, various sources and various ways and carried out in natural settings (natural conditions). In the collection of data consists of two sources of 
data, namely: primary sources and secondary sources; then later by using data triangulation, the data is checked for the validity of the data used.

This research was conducted to find out the meaning of the signs and know the cultural identity of Indonesia in the message of public service announcements on TV from the Film Sensor Institutions in 2014 through semiotics. This research uses Pierce's theory which is a grand theory in semiotics, because the ideas are comprehensive and structural descriptive of all panandaan systems (Sobur, 2001).

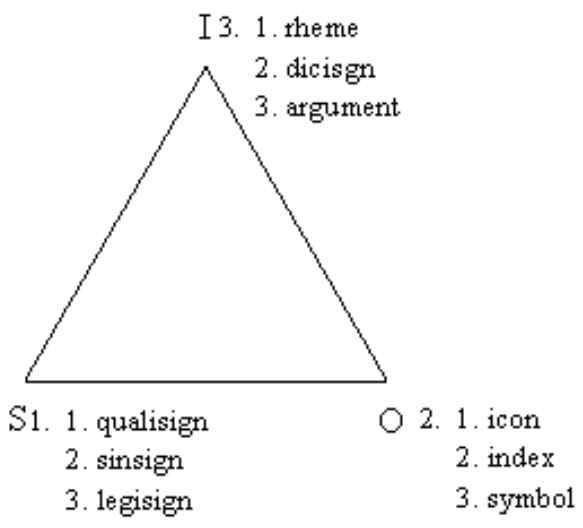

Picture 1. Conceptual framework

Source: Vera, 2014

Researcher used semiotics from the pragmatism of Charles Sander Peirce or called triangle meaning semiotics or known as the theory of triangles meaning. Based on the scope of the discussion, the applied of semiotics can be assessed through the sign system in advert in this study.

Table 1. Trikotomi of Pierce

\begin{tabular}{llll}
\hline \multicolumn{1}{c}{ Name } & \multicolumn{1}{c}{1} & \multicolumn{1}{c}{2} & \multicolumn{1}{c}{3} \\
\hline Sign (S1) & Qualisign & Sinsign & Legisign \\
Object (O2) & Icon & Index & Symbol \\
Interpretant (I 3) & Rhema & Decisign & Argument \\
\hline
\end{tabular}

Source: Deledalle 2000 at Vera. 2014 
For the intention of facilitating the presentation and understanding of research results, the operational concepts presented in this study are as follows.

Table 2. Operational Concepts

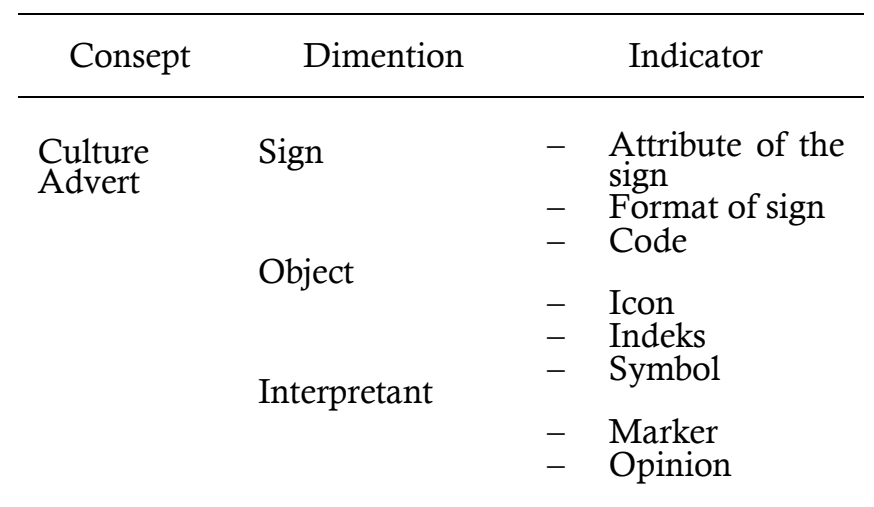

Source: Processed by researcher

Researchers will analyze the signs of Indonesian cultural identity in the message of public service announcements on TV from the Film Sensor Institutions in 2014. According to Pierce there are three types of signs which consist of sign / representament, object (something referred to by sign), and interpretant (the result of the sign's relationship with the object). Here is the analysis of ads by Charles Sanders Pierce's Semiotics Analysis, as follows:

Table 3. Operational Concepts The analysis of ads by Charles

Sanders Pierce's Semiotics Analysis

\begin{tabular}{ll}
\hline Sign & The visual of Indonesian cultural identity \\
in the message of public service \\
announcements on TV from the Film \\
Sensor Institutions in 2014 \\
Object & Indonesian cultural identity in the \\
& message of public service announcements \\
& on TV from the Film Sensor Institutions \\
in 2014 & \\
Interpretant & The mean of Indonesian cultural identity \\
& in the message of public service \\
& announcements on TV from the Film
\end{tabular}


Sensor Institutions in 2014

Source: Processed by researcher

\section{Results and Discussion}

\section{Culture and Cultural Identity of Indonesia}

Derived from the Sanskrit; buddhayah is a word with the same meaning; means 'cultivating, doing', especially cultivating land or farming. Then developed, culture has meaning as all the efforts and actions of humans to cultivate land and change nature (Koentjaraningrat, 2009).

J.J. Honigmann distinguished three cultural phenomena; namely: (1) ideas, (2) activities, and (3) artifacts. Three forms, namely: (1) The form of culture; as a complex of ideas, ideas, values, norms, rules, and so on, (2) the form of culture as a complex of human activity in society of the actions of the patterned, and (3) the form of culture as the result of human work in the form of objects (Koentjaraningrat, 2009).

There are seven elements as the essence of the contents of each culture that can be found from every culture in the world; namely: (1) Language, (2) Knowledge systems: the natural surroundings, the natural flora in the area where they live, the flora of the flora in the area where they live, the substances or objects in their environment and raw materials, the human body, the properties and human behavior, space and time, (3) social organizations, (4) systems of living equipment and technology, (5) systems of living, (6) religious systems; namely: belief systems, religious ceremonies: where religious ceremonies are performed, times when religious ceremonies are carried out, objects and instruments of ceremonies, people who perform and lead ceremonies, and a people who attend to the religion, and (7) Arts (Koentjaraningrat, 2009).

Related to the discussion of Indonesian cultural identity is a legacy that has the characteristics, forms, and technology that has these cultural markings made in Indonesia related to long experience of culture and its development is shaped according to its history. The subject of "the Indonesian" is more determined by which reverse or technological features determine the culture or "fabrication of Indonesia", meaning 
that it is made in Indonesian territory today, however, the place of discovery is outside of Indonesia (Sedyawati, 2012).

\section{The Ads}

In general, it can be said that advertising is a tool for advertisers both individuals and institutions or institutions that are business, social and political in communicating products in the form of goods, services or ideas or ideas to the public for a fee. By developing a strategy that you want to say on the ad and how to say it. Advertisements are launched in the form, role and type that depends on the communication goals that the advertiser wants to achieve.

Advertising is defined as everything that is paid communication. Advertising is an important part of product promotion; both in the form of goods, services, and ideas even companies that are paid for by sponsors. To reach a broad audience with the aim of linking clear sponsors with buyers (target audience), advertising using mass media and interactive media serves to provide information about products (goods, services, and ideas) (Kertamukti, 2015) dan (Moriarty et al., 2011). Whereas, in designing and developing message advertising strategies, producers will apply art and science; about what ads want to communicate about brands and their creative strategies, and how they want to reflect claims for brands (Kotler \& Keller, 2012). There are four main roles of advertising in society and business; namely: marketing, communication, economics, and society. With seven types of advertising when viewed in an advertising situation, namely: brand advertising, retail or local advertising, direct-response advertising, business-to-business advertising, institutional advertising, also called local advertising, non-profit advertising, and public service announcments (PSAs) (Moriarty et al., 2011).

The role of communication and society that is appropriate and related to the research on Indonesian cultural identity in the message of public service announcements at television from Film Sensor Institutions in 2014. Advertising is a form of communication which is a message about a product delivered to consumers. The role of society; advertising also has a social role. As said by Moriarty et. al. (2011), advertising also 
has an educational role because it teaches us about new products and utility, the type of which is public service announcements (PSAs).

\section{The TV Ads and Advertising Messages}

TV Ads is unique in advertising. Containing moving images and words that are not read but heard, TV commercials have two very important strengths (Moriarty et al., 2011). First, TV Ads as an effective means of demonstrating persuasive, real, and clear product attributes. Second, TV Ads can describe users and user imagery, brand personality or other intangible things dramatically (Kotler \& Keller, 2012). Meanwhile, TV advertising messages like television media are built with two components, namely: audio and visual. Therefore, TV Ads are moving images; combining images with words in creative concepts and stories at the same time. It consists of two elements: audio and video which apply visual storytelling (Lee \& Johnson, 2015).

\section{Public Service Announcements and Messages}

Public service announcements are social or non-commercial in nature, inviting or contributing to the community; to do something or not do something for the common good, to go for something better. The message to be conveyed is adjusted to the theme to be raised. Public Service Announcements (PSAs) are advertisements that convey information and are used to invite or educate audiences with the ultimate goal of social benefits rather than economic benefits. Material of the message delivered in the form of public information so that the exposed audience will do something good. Accordingly, advertising is designed to promote the welfare of the community and operate for the benefit of the community (Lee \& Johnson, 2015). When seen from the suitability of the theme, there are four groups of message emphases in public service announcements; namely: (1) prohibitions and innuendo, (2) warnings, (3) invocaations or suggestions, and (4) Scientific. Which of the four, the theme of the appeal or advice in accordance with this research. 


\section{Film and Film Sensor}

A film is a work of visual art culture moving with or without sound based on recorded cinematographic principles, which can be displayed or displayed and grouped as an audio visual mass communication media. Film censorship is a process that must be passed by films and film advertisements before they are shown or displayed to the general public. Based on UU No.33 of 2009 it is said that, film is a work of cultural art which is a social institution and mass communication media that are made based on cinematographic rules with or without sound and are shown to the public. The film censorship activity is research, assessment, and determination of film eligibility. meanwhile, film advertisements are shown to the general public contained therein; as contained in Undang Undang No.33 Tahun 2009 Bab 1 Ketentuan Umum pasal 1 butir ke-9 about Perfilman (DPR RI \& Presiden RI, 2009).

\section{Semiotics and Charles Sander Pierce's Pragmatism}

Semiotics is the study of signs, used to interpret signs, and give meaning to signs. Semiotic studies to date have distinguished two types of semiotics; namely: communication semiotics, an emphasis on theories about the production of signs and significance semiotics, emphasizing sign theory and understanding in a particular context (Sobur, 2012). There are at least nine types of semiotics; namely: (1) analytic semiotics, (2) descriptive semiotics, (3) faunal semiotics (zoosemiotics), (4) cultural semiotics, (5) narrative semiotics, (6) natural semiotics, (7) normative semiotics, (8) social semiotics, and (9) structural semiotics (Sobur, 2012).

Pierce made important contributions to the logic of philosophy and mathematics, especially semiotics. His opinion, the theory of semiotics in the form of his work on the sign inseparable from logic (Sobur, 2012). It is known as the triadic model and the trichotomic concept which consists of: representament; function as a sign, interpretant; refer to the meaning of the sign, and object; something that refers to a sign (Vera, 2015). 
Analytic semiotics used in this study, namely semiotics which analyze the sign system. To find out the meaning of the signs of Indonesian cultural identity in the message of public service announcements on TV from the Film Sensor Institutions in 2014 by referring to Pierce's triangle meaning theory which consists of sign, object, and interpretant).

\section{Research Result}

The overview of public service announcements on TV from the Film Sensor Institutions in 2014

The public service announcements on TV from the Film Sensor Institutions in 2014 presented Swa Censorship to the public. The advertising message is designed in scenes. One scene includes several shoots from different angles. The big idea of the self-censorship visual translation is to include some of Indonesia's cultural diversity as the contents of the message contained in the creative concept. The contents of the message are packaged into a discussion between the Film Sensor Institutions represented by the Chair of the Film Sensor Institutions and the film community represented by the Film Producer and Assistant Producer within 30 seconds.

Indonesian cultural identity in the message of public service announcements on TV from the Film Sensor Institutions in $\mathbf{2 0 1 4}$

Indonesian cultural identity in the message of public service announcements on TV from the Film Sensor Institutions in 2014 in the form of videos, namely:

Art, namely: (i) Ma'badong; in the form of videos of people dressed in black standing in a row forming a circle doing a typical movement against the background of traditional houses roofed like a ship. Badong is the traditional lyrics of the death of the Toraja people (Sande, 1986). (ii) Perang dance; War Dance; in the form of a video of a crowd of people on the ground who dressed in traditional warfare typical of the ethnic Papuans carrying various types of weapons such as spears, bows, arrows and so forth. Performed at a ceremony when leaving for the battlefield by the people of Irian Jaya (Papua) (Soegiarto, 1980: 170). 
(iii) Batik; this is a video of clothes with typical motifs such as batik motifs worn by an old woman smiling looking ahead. Refers to fabrics with patterns produced by the wax material (Dedi, 2014). (iv) Ma'randing dance; in the form of a video of three people dressed in traditional warfare with ornaments on their heads and wearing white sashes and Toraja writings. (v) Papuan traditional clothing; in the form of videos of traditional Papuan men's and women's traditional clothing and Papuan writings. (vi)Traditional Batak's woof; Traditional Batak cloth; In the advertisement, the traditional cloth worn by an old woman smiles and spun yarn with the tool in front of her, also the inscription of North Sumatra. Ulos is a typical Batak woven scarf (Karmila, 2010). (vii) Tari Pendet; a woman who is dancing in a traditional Balinese longsleeved dance costume and a video of a woman who is dancing in a traditional Balinese dance form. It is a ceremonial dance to be presented to gods (Agung, 1981). (viii) Kecak dance; a woman who is dancing in a traditional Balinese long-sleeved dance costume and a video of a woman who is dancing in a traditional Balinese dance form. It is a ceremonial dance to be presented to gods. (ix) Wayang Golek; young people see the dominant red display and in the display there are puppet goleg whose hands are moved. Golek is one type of Trimatra Puppet made from round-piston wood material by knitting with a knife (Suryana, 2002). (x) Pencak Silat; a boy dressed in black against a background of green trees was doing a typical movement. Pencak Silat is one of the arts and culture that has a variety of styles that continue to survive, including the flow of Cimande, Cikalong, Ciwaringin, etc (Sopandi et al., 1992).

Religion System, namely (i) Ceremonies for the death of Toraja; people dressed in black in a circle doing a typical movement against the background of a traditional house with a roof like a ship parading a small house like a miniature traditional house like the one in the background. (ii) Upacara Ma'palao it means to march the body to the field where the last rites were held. (iii) Kuburan tradisional Toraja; Holes and three human-shaped statues are found on a rock cliff. Liang Batu is the place where the bodies were buried (Yusuf, 1993). (iv) Candi Prambanan; slender buildings that rise above are made of natural stones and there are several forms of stupas on top of it such as the uniqueness 
of a temple building, the Prambanan temple and the Jogja inscription. Prambanan Temple is also known as Lara Jonggrang Temple and this name is associated with local folklore that developed until now, standing Brahma temple, Shiva temple and Wishnu temple, there are also three temples which are usually referred to as Wahana temples and several other small temples (Ibrahim, 1996).

Life and Technology Equipment System, namely: (i) Traditional Batak fabric making; In the form of a video of an old woman smiling in traditional traditional clothes doing a spinning yarn with the tool in front of her and the writing of North Sumatra. (ii) Tools and activities for pounding rice or grain; In the form of a video of several women holding long logs and swinging them up and down like hitting something on a log like a boat. Wooden mortar is a kitchen tool used for pounding grain or for pounding rice (Soedjono, 1994). (iii) Toraja traditional house; a video of traditional houses that has a roof like a ship which is the background of a video of people dressed in black in a circle and a video of three people dressed in traditional Toraja warfare with head ornaments.

Visual and Meaning of Indonesian Cultural Identity in the message of public service announcements on TV from the Film Sensor Institutions in 2014

From the research results, there are analytical messages about Indonesian Cultural Identity in the message of public service announcements on TV from the Film Sensor Institutions in 2014, as follows.

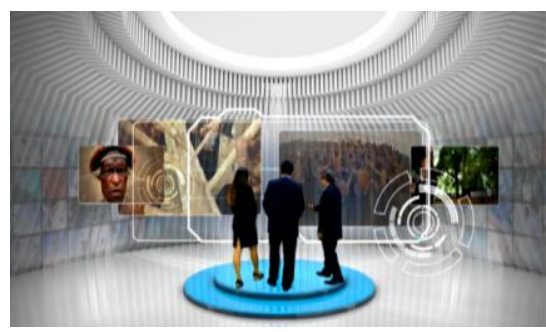

Picture 2 .Visual Images and Semiotic Analysis

(The Chairperson of LSF, Producer, and Assistant Producer Wat the Impressions of Indonesian Cultural Diversity) 
There is a picture that shows the wealth of the Indonesian people about the arts, culture, and customs that are owned from Sabang to Merauke, from Miangas to Rote Island. This cultural diversity is an invaluable asset that can provide added value and added value both in the economic and non-economic aspects. This is what was raised by the Film Sensor Institutions by communicating to the film community and the general public that traditional culture can co-exist and synergize with the advancement of time and the advancement of technology in a professional manner.

Through TV's Ad, the Film Sensor Institutions visually translates the synergy between modernization and technological progress with Indonesian traditional culture. Film can not be separated from technology with all forms of sophistication and professionalism of the people of the video itself. Proven, the special effects of a film resulted from the sophistication of the existing computer application technology as well as the professionalism of the film community in doing their work. Thus, this gives the possibility for Indonesian cultural diversity to be one of the drivers in the advancement of the film industry in Indonesia.

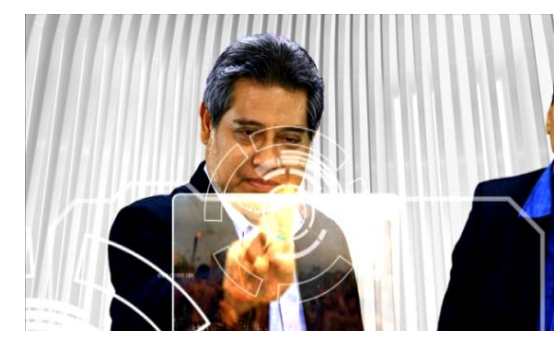

Picture 3. Visual Images and Semiotic Analysis

(LSF Chair and Producer Watch Indonesian Cultural Impressions of Kecak Dance from Bali)

Kecak dance is a colossal dance from Bali. This dance is so wellknown in Indonesia that foreign countries have even become a mustvisit tourist destination in Bali. This dance is danced by Balinese men and not only displays the cohesiveness of the movement, but also contains the meaning of togetherness in a difference to produce harmony and beauty of a dance. 
Other meaning, the picture actually shows the diversity of Indonesian culture which has its own identity and can coexist with the advancement of existing technology. This is an invaluable asset, as one of the elements in advancing the film industry in Indonesia and naturally will support many people working in the industry. Described by the Chairman of the LSF (witnessed by a Producer) who pressed a virtual screen containing a video of the Kecak dance from Bali that has been famous both domestically and abroad. In the making videos, this dance is done colossally by many people who are professionals in their fields.

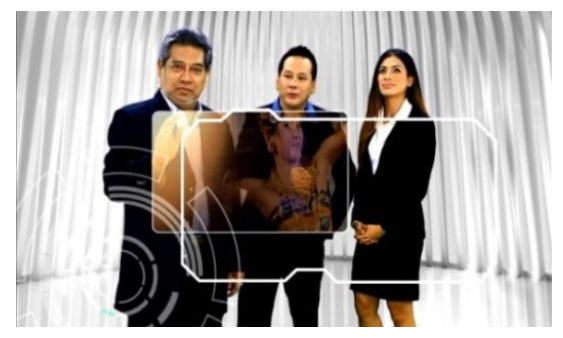

Picture 4. Visual Images and Semiotic Analysis

(The Chairperson of LSF, Producer, and Assistant Producer Watch the Impressions Indonesian Culture of Pendet Dance from Bali)

Existing images as a picture of professional and modern people, who have advanced thinking in accordance with the development of the era and existing technology. They see Pendet Dance which has tenderness, harmony and togetherness as a Balinese dance. It symbolizes the beauty of the harmonization of synergy between the diversity of Indonesia's traditional culture that has an identity and characteristics with the development of the era and technological advancements.

Advances in technology can advance traditional Indonesian culture and Indonesian traditional culture can help technological advancements and the development of the era so that it can be accepted by the community wisely. With this video, the Film Sensor Institutions visually translates the synergy between modernization and technological progress with traditional Indonesian culture. So that it is possible that the diversity of Indonesian culture can be one of the drivers in the advancement of the film industry in Indonesia. 


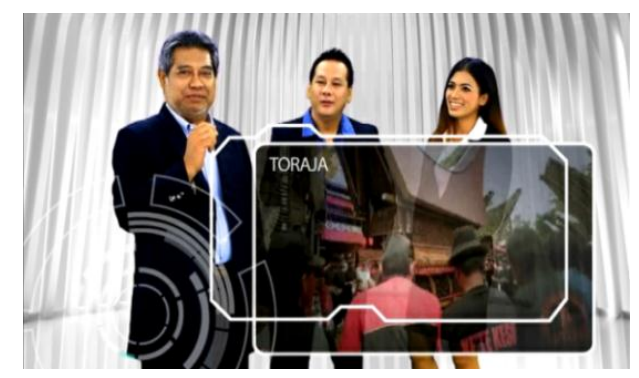

Picture 5. Visual Images and Semiotic Analysis

(The Chairperson of LSF, Producer, and Assistant Producer Watch the Impressions Indonesian Culture of Culture from Toraja)

The picture depicts professional and modern people who have advanced thinking in accordance with the development of the era and the existing technology watching a variety of Indonesian cultures originating from Toraja. Visualization that symbolizes struggle, respect, ritual, and kinship to maintain the tradition of ancestral heritage as a cultural characteristic possessed by Toraja in particular and Indonesia in general.

The Film Sensor Institute wants to communicate to the film community and the general public; that there needs to be a struggle, respect, ritual and kinship to maintain the traditional culture of the Indonesian people. Hopely, this can survive and develop throughout the ages and synergize with each other with the advancement of time and the advancement of existing technology.

The video shows visually that to build synergy between modernization and technological advancement, with traditional Indonesian culture, struggle, respect, rituals, and a sense of belonging like family to the culture are needed. Making a film is indeed needed a struggle, mutual respect, a high routine, and mutual assistance between fellow film workers like their own family. 


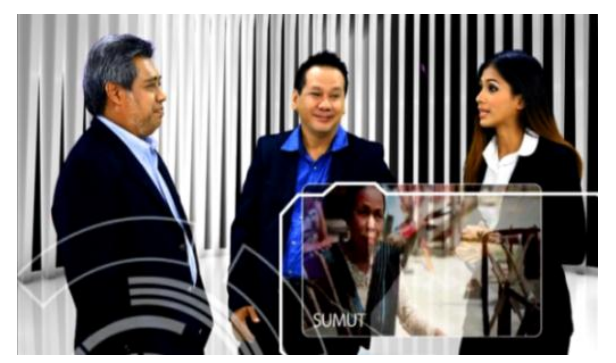

Picture 6. Visual Images and Semiotic Analysis

(The Chairperson of LSF, Producer, and Assistant Producer Watch the Impressions Indonesian Culture of Culture from Papua)

In the past, Papua was named Irian Jaya, which had a very unique identity with its own characteristics and could be known from its culture and customs. this can be seen from the traditional clothing worn by one of the Papua's tribes. They wear red headdresses, necklaces, and decorate their faces and bodies with white paint and without using a breastplate. In addition, the arts possessed as a picture of the life lived by Papua such as Perang dance.

It can be explained that the visualization of this advertisement wants to depict the lives of Papuan people who are so traditional, close to the natural surroundings and still maintain their customs as Papuans. Papuan men still uphold the traditions they have by fighting to defend their self-esteem and customs drawn from the art of Perang dance.

Through the video, the Film Censorship Institution visually translated its desire to communicate a symbiosis of mutualism between modernization and technological progress with Indonesian traditional culture that could be created. this can be done through endless struggles, blazing passion, sincere affection and shared responsibility for the culture. then, as needed is the making of a quality film, has values, education, and inspirational as well as deserves to be a spectacle and guidance for the audience. 


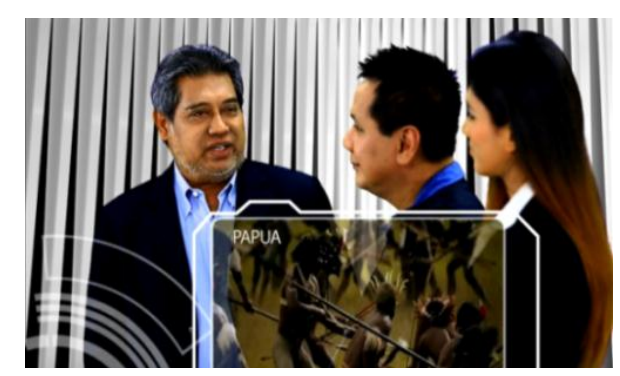

Picture 7. Visual Images and Semiotic Analysis

(The Chairperson of LSF, Producer, and Assistant Producer Watch the Impressions Indonesian Culture in the Form of Culture from North Sumatra)

In many Indonesia's customs, the role of women in preserving traditional culture is very important and very prominent. Implied by the visualization of an old woman smiling while spinning a yarn with a tool in front of her. He wore a traditional cloth from North Sumatra (North Sumatra), which is identical with the Batak culture in dressing, the Ulos cloth. The perseverance and compassion and determination of Batak women in struggling to maintain and preserve the Batak culture, certainly become a strength for the cultural identity of the Indonesian nation.

This description can explain that it is not only the love of culture that is needed for women towards the survival of their traditional culture, but also the perseverance and affection for that culture is needed. Like making traditional cloth and wearing it at important regional and national events and passing it on to future generations. Film Sensor Institution translates visually and wants to communicate, that to preserve and create mutual need between Indonesian traditional culture and modernization and technological progress, it requires a sincere perseverance and love for that culture. It also requires perseverance with sincere affection like the perseverance and affection of a woman for film workers. So, Indonesia's women are able to produce a film that has moral values and educational values, quality in terms of cinematography and is worthy of being a spectacle and guidance for its audience. 


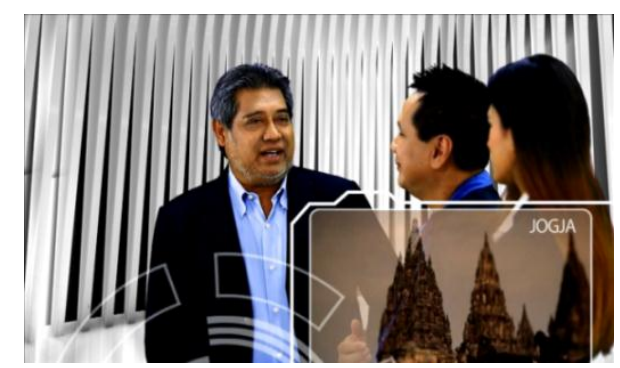

Picture 8. Visual Images and Semiotic Analysis

(The Chairperson of LSF, Producer, and Assistant Producer Watch the Impressions Indonesian Culture is Culture from Yogyakarta)

Prambanan Temple is the largest Hindu temple in Indonesia. This is one of the achievements of the splendor of Hinduism found in Yogyakarta and its preservation is still maintained. This grandeur is reflected in the unique architecture of the building that stands out with three large temples representing the three main deities in Hinduism namely the Brahma temple, the Shiwa temple and the Wishnu temple. It is necessary to sacrifice both material and non material from all parties to build the grandeur. It also requires seriousness, sincerity, tenacity, togetherness, mutual assistance, and an ongoing spirit of struggle that continues for a long time. Thus, this grandeur manifests as a cultural monument that we can still see and enjoy until now.

The picture can also be interpreted that to build and preserve a cultural splendor with the noble values contained therein, it is not as easy as turning the palm of the hand. Moreover, the temple was built through a long process and unyielding sacrifice which until now has become a monument that will be seen by later generations and recognized by other nations.

Through the video, the Film Sensor Institute wants to translate visually and communicate that the grandeur of a culture requires a long process of sacrifice, seriousness, sincerity, tenacity, togetherness, mutual assistance and an ongoing and ongoing fighting spirit. By adopting current technological advancements so that it becomes a monument that symbolizes the splendor of its cultural perceptions. This is also needed by the film community to produce a magnificent and monumental film like the splendor of Prambanan Temple. 


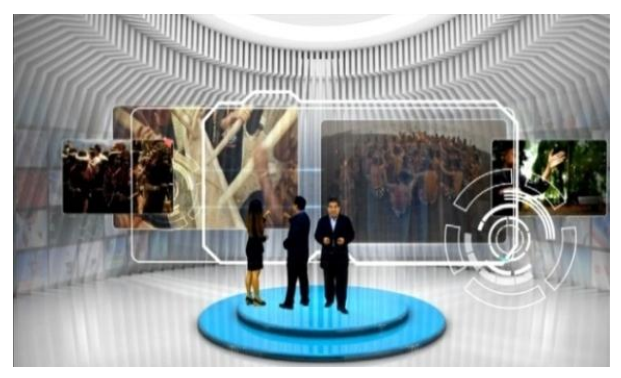

Picture 9. Visual Images and Semiotic Analysis

(The Chairperson of LSF Gives Testimony with Background Producer and Assistant Producer View Impressions

Indonesian Cultural Diversity)

There are so many and varied arts, cultures and customs by the Indonesian people. There are also many opportunities that can be used and taken. No less important and special attention is needed even handling is to be more creative and make diversity acceptable, survive, and develop throughout the ages. Thus, Indonesia's diversity is still wellknown to foreign people and becomes a world-class tourist destination.

The picture can be interpreted that the diversity of arts, culture and customs possessed by the Indonesian people, as a wealth that is very valuable and can provide added value. In addition, public service announcements can be a powerful promotional tool by providing a touch of technology from the times. The diversity of Indonesian traditional culture can be an inspiration in a film and then provide economic added value and promotion of tourism for the surrounding community, local and central government.

The Film Sensor Institution visually translates how a collaboration takes place between technological sophistication and the diversity of Indonesia's traditional culture. Films that incorporate cultural elements in them and combine them with technological sophistication have succeeded in becoming films that are acceptable, enjoyed by many viewers, and bring material benefits. And no less important, the popularity of a culture contained in the film. It is time for the Indonesian film community to take up themes that incorporate the diversity of Indonesian culture. Thus, this opens up opportunities for Indonesia's 
cultural diversity to provide added value, known to foreign countries and become a tourist destination along with the development of the Indonesian film industry.

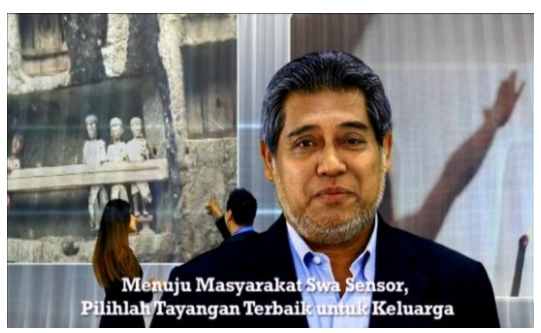

Picture 10. Visual Images and Semiotic Analysis

(The Chairperson of LSF Gives Testimony with Producer Background and Assistant Producers Watch Impressions of Indonesian Cultural Diversity)

Bali and Toraja, two regions have a diversity of cultures, arts and traditions in Indonesia to foreign countries. Also, it has become a popular tourist destination. Both have many colossal traditions and cultures, such as traditional ceremonies for death and clustered houses. The tradition and culture are still preserved to this day.

This picture is a cut of the scene in The Film Sensor Institution's public service announcement which testimonies about the diversity of culture, art and tradition as a distinct identity of Indonesia. The diversity of culture, arts and traditions is an invaluable asset, as one of the elements that not only advances the Indonesian film industry. But broader than that, cultural diversity, art and tradition can also advance economic life and build the identity of the Indonesian people as a nation rich in cultural diversity in the world.

In addition, an invitation to the general public to choose good shows according to themselves in order to create a community that can censor their own shows to be watched. For the film community, the initial process of censorship is to choose quality themes as a spectacle. It is possible to prioritize choosing themes with Indonesian cultural identity.

Through two cultural videos and there is written "Towards a SelfCensorship Society, Choose the Best Impressions for Families" which is 
packaged in a virtual screen and seen by professionals, modern, and has advanced technology in suits and blazers. The Film Sensor Institution translates visually, that for the film community the censorship process of a film can begin through the selection of themes and film titles such as selecting themes which can include a variety of Indonesian traditions and culture. For the general public; the censorship process can be carried out on its own by selecting its own shows suitable for itself, such as the age limit criteria and airtime for television shows. Thus, this allows the creation of a self-censorship society, an independent society that conducts its own censorship of the shows they watch.

\section{Conclusion}

Based on the research results obtained by analyzing and describing the findings of the data presented, the following conclusions can be obtained. (1) Indonesian cultural identity contained in the 2014 Film Censorship Institute public service TV ad message. It is known that there are a variety of Indonesian cultural identity in the message of Public service announcements at television from Film Sensor Institutions in 2014. There are 10 Ten elements of culture in the form of art such as dance, traditional clothing, traditional cloth, puppet art, and martial arts. There are three cultural elements in the form of a religious system, namely: the traditional ceremony of the death of the Toraja, the traditional Toraja grave, and the Prambanan temple. There are three cultural elements in the form of living equipment and technology systems, namely: making traditional Batak cloths, tools and activities for pounding rice or grain, and Toraja traditional houses. All of these cultural identities are pictures of traditions that have philosophical values and wisdom possessed by the Indonesian people. (2) Forms of Indonesian cultural identity in the message of Public service announcements at television from Film Sensor Institutions in 2014. There are three forms of Indonesian cultural identity in the message of Public service announcements at television from Film Sensor Institutions in 2014, namely art, religious system, and living equipment and technology system. (3) Meaning visual of Indonesian cultural identity in the message of Public service announcements at television 
from Film Sensor Institutions in 2014. There are several meanings contained in the Indonesian cultural identity in the message of Public service announcements at television from Film Sensor Institutions in 2014. First, the Indonesian cultural diversity video is packaged in the form of a virtual screen as a translation of a film world full of technological sophistication. Second, the diversity of Indonesian culture is an invaluable asset that can provide better value in terms of economic and non-economic aspects in improving the welfare of people physically and spiritually. Third, traditional culture can side by side and synergize with the advancement of time and the advancement of existing technology, so that technological advancements can advance Indonesian traditional culture and Indonesian traditional culture can help technological advancement and advancement of time so that people can be accepted wisely. Fourth, it is possible that Indonesian cultural diversity can be one of the drivers in the advancement of the film industry in Indonesia and film becomes a promotional tool for Indonesian cultural diversity.

\section{Bibliography}

Agung, A. A. G. P. (1981). Beberapa tari upacara dalam masyarakat Bali.

Proyek Media Kebudayaan Jakarta, Direktorat Jenderal Kebudayaan, Departemen Pendidikan dan Kebudayaan.

Dedi, D. (2014). Sejarah batik Indonesia. Sarana Panca Karya Nusa.

DPR RI, \& Presiden RI. (2009). Undang-Undang Nomor 33 Tahun 2009Pusat Data Hukum Online.com. Lembaran Negara Republik Indonesia.

Ibrahim, M. (1996). Kompleks candi prambanan dari masa ke masa (M. Ibrahim, Ed.). Direktorat perlindungan dan pembinaan peninggalan sejarah dan purbakala.

Karmila, M. (2010). Ragam kain tradisional nusantara: Makna, simbol, dan fungsi. Jakarta: Bee Media.

Kertamukti, R. (2015). Strategi kreatif dalam periklanan. Jakarta: Raja Grafindo Persada.

Koentjaraningrat. (2009). Pengantar ilmu antropologi (9th ed.). Jakarta: Rineka Cipta. 
Kotler, P., \& Keller, K. L. (2012). Marketing Management. Pearson.

Lee, M., \& Johnson, C. (2015). Prinsip-Prinsip Pokok Periklanan Dalam Perspektif Global-Edisi Pertama Cetakan Ke-3. Kencana. https://openlibrary.telkomuniversity.ac.id/pustaka/103313/prin sip-prinsip-pokok-periklanan-dalam-perspektif-global-edisipertama-cetakan-ke-3.html

Moriarty, S., Mitchell, N., \& Wells, W. (2011). Advertising Ed.8. Jakarta: Kencana.

Pujiyanto. (2014). Iklan Layanan Masyarakat. Andi. https://openlibrary.telkomuniversity.ac.id/pustaka/65728/iklanlayanan-masyarakat.html

Sande, J. S. (1986). Badong sebagai lirik kematian masyarakat Toraja. Departemen Pendidikan dan Kebudayaan, Proyek Penerbitan Buku Sastra Indonesia dan Daerah.

Sedyawati, E. (2012). Budaya Indonesia: Kajian arkeologi, seni, dan sejarah. Divisi Buku Perguruan Tinggi, Jakarta: Raja Grafindo Persada.

Sobur, A. (2012). Analisis teks media: Suatu pengantar untuk analisis wacana, analisis semiotik dan analisis framing. Bandung: Remaja Rosdakarya.

Soedjono, S. (1994). Album Alat Musik Tradisional (Bengkulu, DKI Jakarta, Jawa Tengah, Jawa Timur, Kalimantan Barat). Direktorat Jenderal Kebudayaan.

Soegiarto, N. (1980). Monografi daerah Irian Jaya. Proyek Media Kebudayaan Departemen Pendidikan dan Kebudayaan.

Sopandi, A., Kartakusumah, D. H., Seputro, W. Y., Soediarso, U., \& Burhan, M. J. (1992). Pencak silat. Dinas Kebudayaan DKI Jakarta.

Sugiyono. (2013). Kualitatif, dan Kombinasi (Mixed Methods) (6th ed.). Bandung: Alfabeta.

Suryana, J. (2002). Wayang golek Sunda: Kajian estetika rupa tokoh golek. Bandung: Kiblat Buku Utama.

Vera, N. (2015). Semiotika dalam Riset Komunikasi. Jakarta: Ghalia Indonesia.

Yusuf, W. P. (1993). Upacara tradisional (upacara kematian) daerah Sulawesi Selatan. [Jakarta]: Departemen Pendidikan dan Kebudayaan, 
Direktorat Jenderal Kebudayaan, Proyek Penelitian, Pengkajian dan Pembinaan Nilai-nilai Budaya Sulawesi Selatan. 